\title{
Chronic ethanol ingestion enhances GnRH-stimulated LH responses of castrated male dogs*
}

\author{
R. W. Pamenter, T. W. Boyden and M. A. Silvert $\dagger$ \\ Section of Endocrinology, Department of Internal Medicine, and †Section of Urology, \\ Department of Surgery, Veterans Administration Medical Center, Tucson, Arizona 85723, and \\ University of Arizona College of Medicine, Arizona Health Sciences Center, Tucson,
} Arizona 85724, U.S.A.

\begin{abstract}
Summary. Dogs were given no ethanol, $1.28 \mathrm{~g}$ ethanol $/ \mathrm{kg}$ and $1.92 \mathrm{~g}$ ethanol $/ \mathrm{kg}$ daily for 4 weeks immediately after castration. Plasma LH concentrations, basal and in response to $100 \mu \mathrm{g} \mathrm{GnRH}$, were measured before and at 2 and 4 weeks after castration. Basal LH levels after castration increased significantly $(P<0.005)$ within each group but were not significantly different between groups. GnRHstimulated LH responses were similar before and at 2 weeks after castration, but at 4 weeks the dogs given $1.92 \mathrm{~g}$ ethanol $/ \mathrm{kg}$ had a significantly $(P<0.05)$ greater response than did the control dogs. It is concluded that daily ethanol ingestion in the amounts employed in this study does not impair hypothalamic-pituitary function in male dogs.
\end{abstract}

\section{Introduction}

Chronic alcohol ingestion is associated with marked changes of the hypothalamic-pituitarygonadal axis in men and in rats (Baker et al., 1976; Van Thiel, Gavaler, Cobb, Sherins \& Lester, 1979). Data regarding the specific site or sites of alcohol-induced injury are conflicting and largely inferred from intact men and animals (Cicero \& Badger, 1977). Van Thiel \& Loriaux (1979) have pointed out that some of the varied results obtained from examining the hypothalamic-pituitary-gonadal axis of alcoholic men may be explained on the basis of patient selection, i.e. whether or not the subjects were ill at the time of the study. Also, due to the variation in nutritional status and the unreliability of drinking histories from chronic alcoholics, data from this type of study, although valuable for correlating liver pathology and drinking history to hypothalamic-pituitary-gonadal dysfunction, do not shed light on the direct effect of ethanol on hypothalamic-pituitary-gonadal function.

Interpretation of data from intact normal men and animals, and men with liver disease, is valuable but does not allow identification of the specific site(s) of ethanol toxicity. In this study the castrated male dog was used to examine the chronic effects of ingested ethanol on the hypothalamic-pituitary unit.

\section{Materials and Methods}

The 18 adult greyhound dogs used weighed $25-35 \mathrm{~kg}$. Immediately after castration the 12 experimental dogs were fed ethanol daily at a dose of $1.28 \mathrm{~g} / \mathrm{kg}$ (Group 2) and $1.92 \mathrm{~g} / \mathrm{kg}$ (Group 3). The ethanol was thoroughly mixed with two cans of standard dog food that was

* Reprint requests to Dr T. W. Boyden, Veterans Administration Medical Center, Tucson, Arizona 85723, U.S.A. 
consumed within 5-15 min and then dry food was provided ad libitum each day. Control dogs (Group 1) received similar food without ethanol.

Before castration, all the dogs in Groups 1 and 3 were fitted with an indwelling foreleg venous cannula and a GnRH stimulation test was performed. This test consisted of removal of two basal blood samples followed by an intravenous injection of $100 \mu \mathrm{g} \mathrm{GnRH}$ (Vega Biochemicals, Tucson, Arizona) and subsequent blood samples at 10, 20, 30,60, 90 and $120 \mathrm{~min}$ for LH determination. Castration was performed using standard, sterile surgical techniques after inducing anaesthesia with pentobarbitone sodium $(30 \mathrm{mg} / \mathrm{kg})$. The dogs in Group 2 were castrated without having a prior GnRH test. The experimental diets were begun the day following castration. A repeat $\mathrm{GnRH}$ test was performed at 2 and 4 weeks after castration in all 3 groups. To eliminate any acute effect of ethanol administration on the GnRH tests ethanol was not given to the dogs in Groups 2 and 3 on the day of the repeat GnRH tests until after the test was performed. This resulted in a 3-h delay of the usual ethanol feeding. The blood samples were immediately centrifuged at $4^{\circ} \mathrm{C}$ and the plasma was stored frozen at $-20^{\circ} \mathrm{C}$ until the $\mathrm{LH}$ assays were performed.

Blood for alcohol determination was sampled on random days during the 4 weeks between 1 and $5 \mathrm{~h}$ after ethanol ingestion. A Dupont automated clinical analyser was used to measure blood alcohol concentrations.

Plasma LH was assayed by the double-antibody radioimmunoassay of Niswender, Reichert, Midgley \& Nalbandov (1969). The first antibody used was ovine No. 15 obtained from Dr G. D. Niswender (Colorado State University, Fort Collins, Colorado) which has been validated for use in canine LH assays by Smith \& McDonald (1974). Ovine LH (LER-1056-62) for iodination and canine LH standard (LER-1685-1) were obtained from Dr L. E. Reichert, Jr (Emory University, Atlanta, Georgia). The iodination was performed by the method of Greenwood, Hunter \& Glover (1963) using $1 \mathrm{mCi}{ }^{125} \mathrm{I}$ (Amersham Corp., Arlington Heights, Illinois). Standard curves were prepared in the range of 0.1 to $10 \mathrm{ng}$ and duplicate plasma samples were assayed.

Results were analysed by means of a computer programme based on the methods of Rodbard (1970). Plasma LH responses to injected GnRH are expressed as the area under the LH curve but above the baseline LH value. Simpson's approximation was used to calculate the areas under the curves. Assay quality control was assessed as described by Rodbard, Rayford, Cooper \& Ross (1968) and Rodbard (1974). The intra- and inter-assay variations were 6.6 and $14 \%$, respectively. Minimum detectable $\mathrm{LH}$ was $0.25 \mathrm{ng} / \mathrm{ml}$. To minimize inter-assay variation, control and experimental plasma samples from each experiment were run in the same assay. Statistical significance of the differences was assessed with $t$ tests.

\section{Results}

The dogs in Group 1 lost a significant amount of body weight during the first 2 weeks but precastration values were achieved by 4 weeks. There was no significant change in body weight in Group 2. In Group 3 there was a significant weight loss after 2 weeks that persisted, but did not decline further, until 4 weeks (Table 1).

Mean blood alcohol concentrations peaked $210 \mathrm{~min}$ after ethanol ingestion at $101 \mathrm{mg} / \mathrm{dl}$ in Group 2 and at $183 \mathrm{mg} / \mathrm{dl}$ in Group 3. Obvious signs of intoxication were present in all the dogs fed ethanol, the higher dosage producing severe ataxia and somnolence after each ingestion.

Basal plasma LH concentrations in Groups 1 and 3 were significantly increased at 2 and 4 weeks compared to the precastration value but there were no significant differences between the 3 groups at 2 or 4 weeks (Table 1). Basal values in Groups 1 and 3 were similar $(P>0.05)$. Precastration responses to GnRH were also similar (Text-fig. 1a). 
Table 1. Basal plasma LH concentrations and body weight changes associated with castration in dogs

\begin{tabular}{|c|c|c|c|c|}
\hline \multirow[b]{2}{*}{ Group } & & \multirow{2}{*}{$\begin{array}{l}\text { Before } \\
\text { castration }\end{array}$} & \multicolumn{2}{|c|}{ After castration } \\
\hline & & & 2 weeks & 4 weeks \\
\hline 1 & $\begin{array}{l}\text { LH (ng/ml) } \\
\text { Body weight }(\mathrm{kg})\end{array}$ & $\begin{aligned} 0.74 & \pm 0.57 \\
29.85 & \pm 2.7\end{aligned}$ & $\begin{array}{l}10.31 \pm 1.84^{* * *} \\
26.48 \pm 1.57^{*}\end{array}$ & $\begin{array}{c}9.43 \pm 2.2^{* *} \\
29.03 \pm 1.97\end{array}$ \\
\hline $\begin{array}{l}2 \\
(1.28 \mathrm{~g} \text { ethanol } / \mathrm{kg})\end{array}$ & $\begin{array}{l}\text { LH (ng/ml) } \\
\text { Body weight (kg) }\end{array}$ & $28 \cdot 12 \pm 1 \cdot 17$ & $\begin{array}{l}10.87 \pm 1.21 \\
28.24 \pm 1.34\end{array}$ & $\begin{array}{r}9.40 \pm 2.15 \\
28.19 \pm 1 \cdot 14\end{array}$ \\
\hline $\begin{array}{l}3 \\
(1.92 \mathrm{~g} \text { ethanol } / \mathrm{kg})\end{array}$ & $\begin{array}{l}\text { LH (ng/ml) } \\
\text { Body weight (kg) }\end{array}$ & $\begin{array}{c}1.15 \pm 0.7 \\
28.34 \pm 1.09\end{array}$ & $\begin{array}{l}10.01 \pm 1.17^{* * *} \\
26.23 \pm 1.09^{* * *}\end{array}$ & $\begin{array}{l}13.28 \pm 1.6^{* *} \\
26.69 \pm 1.13^{*}\end{array}$ \\
\hline
\end{tabular}

Values are mean \pm s.e.m. for 6 dogs/group.

Significantly different from value before castration: $*>0.05 ;{ }^{* *} P<0.01 ; * * * P<0.001$ (paired $t$ tests).

+ Not measured.

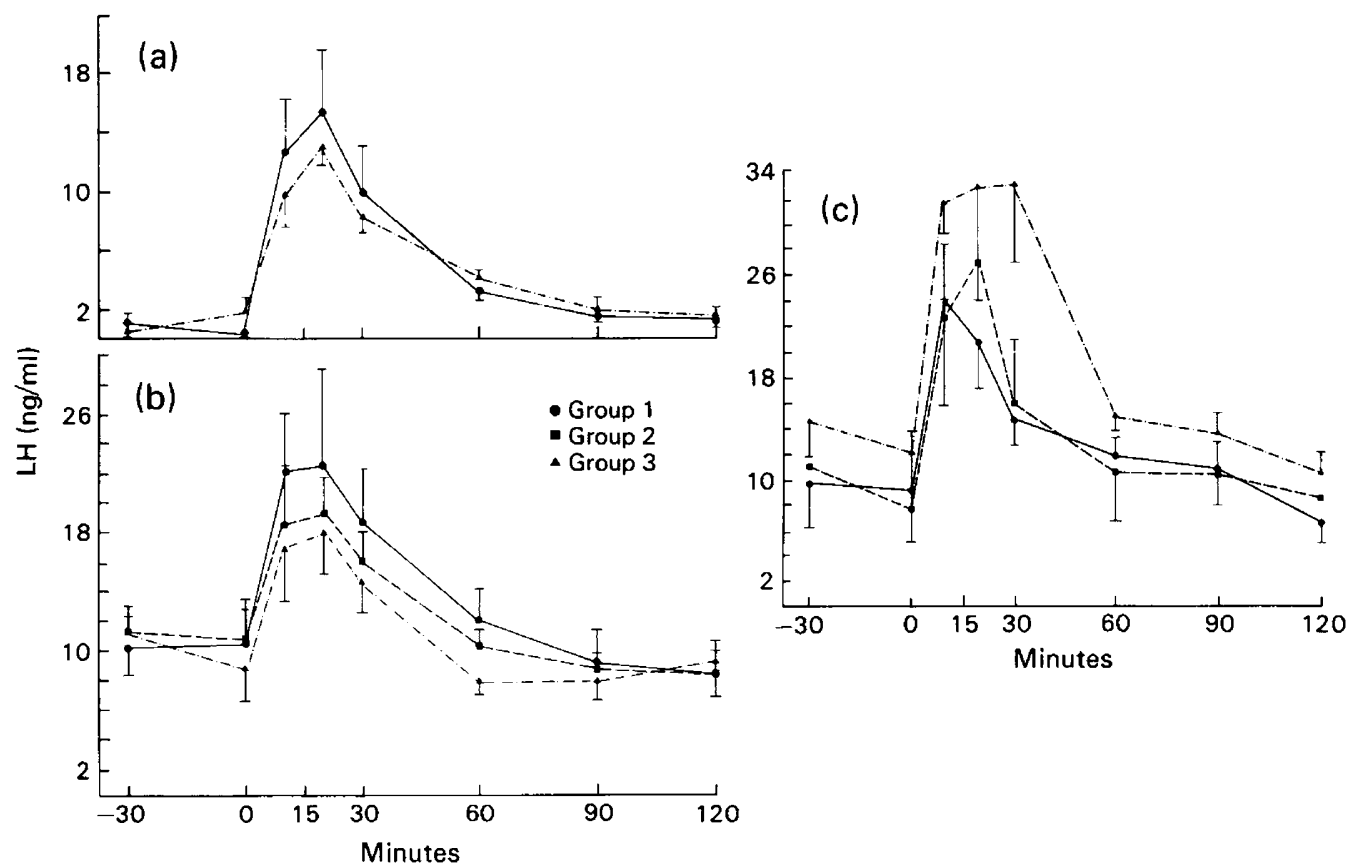

Text-fig. 1. Mean \pm s.e.m. plasma $\mathrm{LH}$ concentrations in response to a $\mathrm{GnRH}(100 \mu \mathrm{g})$ challenge at $0 \mathrm{~min}$ in dogs (a) before castration and at (b) 2 weeks and (c) 4 weeks after castration in Group $1(\mathbf{O})$, Group $2(\square)$ and Group $3(\Delta)$.

At 2 weeks after castration the GnRH-stimulated $\mathrm{LH}$ responses, expressed as the mean \pm s.e.m. area under the LH curve, were $1025 \pm 206,753 \pm 51$ and $686 \pm 132(\mathrm{ng} / \mathrm{ml}) \cdot 120 \mathrm{~min}$ for Groups 1, 2 and 3, respectively (Text-fig. 1b); these were not significantly different. At 4 weeks the LH response was significantly greater $(P<0.05)$ for Group 3 dogs than for those in Group $1(1561 \pm 213$ and $1008 \pm 168(\mathrm{ng} / \mathrm{ml}) \cdot 120 \mathrm{~min}$, respectively, Text-fig. 1c).

\section{Discussion}

Van Thiel et al. (1979) examined adult male rats chronically fed ethanol and found that plasma levels of testosterone were significantly reduced when compared to isocalorically-fed and 
weight-starved controls. No difference in plasma LH levels was observed between the three groups. Cicero \& Badger (1977), in a shorter study using a similar protocol, were unable to demonstrate any significant differences in plasma testosterone or $\mathrm{LH}$ concentrations between ethanol-fed and weight-starved control rats and concluded that the induced weight loss was sufficient to explain any changes in the hypothalamic-pituitary-gonadal axis. Van Thiel et al. (1979) also studied castrated rats and found severely impaired LH responses to GnRH, but these animals had been given ethanol for 134 days before castration.

The amount of ethanol consumed by our dogs resulted in obvious intoxication and blood alcohol levels relevant to human alcohol consumption. At the end of the 4-week study there was no significant change in body weight in the control dogs and those fed the lower ethanol dose although those receiving the higher dose lost a mean of $1.65 \mathrm{~kg}$. Basal LH concentrations in the 3 groups increased to a similar degree after castration, and the values are comparable to those previously reported for normal castrated dogs (Smith \& McDonald, 1974; Vincent, Kepic, Lathrop \& Falvo, 1979). Therefore the increase in basal LH levels after castration was not impaired due to the ethanol ingestion, or the modest weight loss in Group 3. However, ethanol did enhance the pituitary LH response to GnRH in the dogs in Group 3 after ethanol had been ingested for 4 weeks and despite their loss in body weight. The exaggerated $\mathrm{LH}$ response to GnRH appears to be dependent on both the length of ethanol administration and the amount administered since there were no significant differences between the 3 groups at 2 weeks and no effect at 4 weeks in the dogs fed the lower ethanol dose. Van Thiel, Lester \& Vaitukaitis (1978) concluded that ethanol decreased pituitary LH reserves in men. The response in dogs may have been due to an enhanced pituitary LH reserve or to impairment of the clearance of $\mathrm{LH}$ from plasma. These experiments do not allow speculation about which mechanism accounts for the exaggerated plasma LH levels following the injection of GnRH. The differences between our findings and those of others may be explained by the use of castrated dogs rather than intact rats or men, the absence of pre-existing nutritional deficiencies or liver disease in our animals, differences in the amounts of ethanol used in the various studies and differences in experimental design.

Supported in part by a Medical Research grant from the Veterans Administration, Washington, D.C.

\section{References}

Baker, H.W.G., Burger, H.G., De Kretser, D.M., Dulmanis, A., Hudson, B., O'Conner, S., Paulsen, C.A., Purcell, N., Rennie, G.C., Seah, C.F., Taft, H.P. \& Wong, C. (1976) A study of the endocrine manifestations of hepatic cirrhosis. Q. J. Med. 45, 145-178.

Cicero, T.J. \& Badger, T.M. (1977) A comparative analysis of the effects of narcotics, alcohol and the barbiturates on the hypothalamic-pituitary-gonadal axis. Adv. exp. Med. Biol. 85B, 95-115.

Greenwood, F.C., Hunter, W.M. \& Glover, J.S. (1963) The preparation of ${ }^{125}$ I-labelled human growth hormone of high specific radioactivity. Biochem. $J$. 89, 114-123.

Niswender, G.D., Reichert, L.E., Jr, Midgley, A.R., Jr \& Nalbandov, A.V. (1969) Radioimmunoassay for bovine and ovine luteinizing hormone. Endocrinology 84, 1166-1173.

Rodbard, D. (1970) Computer analysis of radioligand assay and radioimmunoassay data. Acta endocr., Copenh., Suppl. 147, 79-103.

Rodbard, D. (1974) Statistical quality control and routine data processing for radioimmunoassays and immunoradiometric assays. Clin. Chem. 20, 12551270.
Rodbard, D., Rayford, P.L., Cooper, J.A. \& Ross, G.T. (1968) Statistical quality control of radioimmunoassays. J. clin. Endocr. Metab. 28, 1412-1418.

Smith, M.S. \& McDonald, L.E. (1974) Serum levels of luteinizing hormone and progesterone during the estrous cycle, pseudopregnancy and pregnancy in the dog. Endocrinology 94, 404-412.

Van Thiel, D.H. \& Loriaux, D.L. (1979) Evidence for an adrenal origin of plasma oestrogens in alcoholic men. Metabolism 28, 536-541.

Van Thiel, D.H., Lester, R. \& Vaitukaitis, J. (1978) Evidence for a defect in pituitary secretion of luteinizing hormone in chronic alcoholic men. J. clin. Endocr. Metab. 47, 499-507.

Van Thiel, D.H., Gavaler, J.S., Cobb, C.F., Sherins, R.J. \& Lester, R. (1979) Alcohol-induced testicular atrophy in the adult male rat. Endocrinology 105, 888-895.

Vincent, D.L., Kepic, T.A., Lathrop, J.C. \& Falvo, R.E. (1979) Testosterone regulation of luteinizing hormone secretion in the male dog. Int. J. Androl. 2, 241-249. 